\title{
Physicochemical and Biological Properties of Oxovanadium(IV), Cobalt(II) and Nickel(II) Complexes with Oxydiacetate Anions
}

\author{
Dariusz Wyrzykowski • Anna Kloska • Joanna Pranczk • \\ Aneta Szczepańska • Aleksandra Tesmar • Dagmara Jacewicz • \\ Bogusław Pilarski • Lech Chmurzyński
}

Received: 20 October 2014 / Accepted: 30 October 2014 / Published online: 7 December 2014

(C) The Author(s) 2014. This article is published with open access at Springerlink.com

\begin{abstract}
The potentiometric and conductometric titration methods have been used to characterize the stability of series of VO(IV)-, $\mathrm{Co}(\mathrm{II})-$ and $\mathrm{Ni}(\mathrm{II})$-oxydiacetato complexes in DMSO-water solutions containing 0-50 \% (v/v) DMSO. The influence of DMSO as a co-solvent on the stability of the complexes as well as the oxydiacetic acid was evaluated. Furthermore, the reactivity of the complexes towards superoxide free radicals was assessed by employing the nitro blue tetrazolium (NBT) assay. The biological properties of the complexes were investigated in relation to their cytoprotective activity against the oxidative damage generated exogenously by using hydrogen peroxide in the Human Dermal Fibroblasts adult (HDFa) cell line as well as to their antimicrobial activity against the bacteria (Bacillus subtilis, Escherichia coli, Enterococcus faecalis, Pseudomonas aeruginosa, Staphylococcus aureus, Staphylococcus epidermidis). The relationship between physicochemical and biological properties of the complexes was discussed.
\end{abstract}

Keywords Oxydiacetate complexes · Cytoprotective activity $\cdot$ Antimicrobial activity $\cdot$ Potentiometric titration · Conductometric titration $\cdot$ Stability constant

\footnotetext{
D. Wyrzykowski $(\bowtie) \cdot J$. Pranczk $\cdot$ A. Tesmar $\cdot$ D. Jacewicz L. Chmurzyński

Faculty of Chemistry, University of Gdańsk, Wita Stwosza 63, 80-308 Gdańsk, Poland

e-mail: dariusz.wyrzykowski@ug.edu.pl
}

\author{
A. Kloska $\cdot$ A. Szczepańska \\ Faculty of Biology, University of Gdańsk, Wita Stwosza 59, \\ 80-308 Gdańsk, Poland \\ B. Pilarski \\ Cerko Sp. z o.o. Sp. K, Al. Zwycięstwa 96/98, 81-451 Gdynia, \\ Poland
}

\section{Introduction}

Polycarboxylate metal complexes have attracted the interest of many research teams because of their extensive applications in wide areas from material to biological sciences [1-7]. The flexible nature of the ligands permits designing and syntheses of new coordination compounds of different architecture and topologies [8]. Moreover, the crystal engineering of coordination-polymeric solids enables a topological control over the crystalline form and hence allows to obtain the material of desired electronic, magnetic, optical or catalytic properties for solid state technologies [9, 10].

The oxydiacetate ion belongs to dicarboxylate ligands, and moreover, it contains the ethereal donor atom that is capable to take part in the coordination to the central atom. The flexibility of this ligand enables to adopt, depending on the kind of metal ion and a method of synthesis, different geometrical conformations from a planar (mer coordination) to folded about the $\mathrm{M}-\mathrm{O}$ vector ( $f a c$ coordination) $[11,12]$. However, ab initio calculations reveal that the mer $\leftrightarrow$ fac energetic barrier is small enough and thus the co-existence of both isomers in the solution at the equilibrium is possible [13]. The flexibility of the geometric transformations around the metal centre as well as the ability of metal ion to undergo the one-electron reduction by superoxide followed by the reoxidation of the reduced metal ion by a second superoxide ion are considered to be one of the factors responsible for the superoxide dismutase (SOD) mimetic activity of the complexes. For instance, oxydiacetate copper complexes, $\left[\mathrm{Cu}(\mathrm{ODA})(\right.$ bipy $\left.)\left(\mathrm{H}_{2} \mathrm{O}\right)\right] \cdot 4 \mathrm{H}_{2} \mathrm{O}$ and $[\mathrm{Cu}(\mathrm{ODA})(4-$ pic) $\left.\left(\mathrm{H}_{2} \mathrm{O}\right)\right] \cdot 2 \mathrm{H}_{2} \mathrm{O}$ where bipy and 4-pic denote 2,2'-bipyridine and 4-picoline, respectively, exhibit a considerable SOD activity $[14,15]$. Furthermore, several metal complexes comprising oxydiacetate as a primary ligand and $\alpha$-diimine as an auxiliary ligand, $\left[\mathrm{M}(\mathrm{ODA})(\right.$ bipy $\left.)\left(\mathrm{H}_{2} \mathrm{O}\right)\right] \cdot \mathrm{xH}_{2} \mathrm{O}\left[M=\mathrm{Cu}^{2+}\right.$ or $\mathrm{Ni}^{2+}, x=4$; $\left.\mathrm{Cr}^{2+}, x=3 ; \mathrm{Co}^{2+}, x=2\right]$ and [VO(ODA)(bipy)] $2 \mathrm{H}_{2} \mathrm{O}$ as well as $\left[\mathrm{M}(\mathrm{ODA})(4-\mathrm{pic})\left(\mathrm{H}_{2} \mathrm{O}\right)\right] \cdot \mathrm{xH}_{2} \mathrm{O}\left[M=\mathrm{Cu}^{2+}\right.$ or $\mathrm{Ni}^{2+}, x=2 ; \mathrm{Cr}^{2+}$, 
$\left.x=3 ; \mathrm{Co}^{2+}, x=4\right]$ and $[\mathrm{Fe}(\mathrm{ODA})(4-\mathrm{pic})] \mathrm{Cl}$, have been found to exhibit antibacterial activities $[14,15]$.

The subject of our continuous interest are polycarboxylate metal complexes since it has been found that the oxydiacetate complexes of VO(IV), $\mathrm{Co}$ (II) and $\mathrm{Ni}$ (II) can protect effectively the mouse hippocampal neuronal cell line (HT22) against an oxidative stress induced by $\mathrm{H}_{2} \mathrm{O}_{2}$ [16]. Hydrogen peroxide is the most frequently mentioned agent responsible for the oxidative stress in neurodegenerative diseases, brain strokes and atherosclerotic diseases. The present study constitutes a continuation of our earlier efforts on the characterization of physicochemical and biological properties of the oxydiacetate complexes [16-18]. The potential application of lowmolecular weight coordination compounds as therapeutic superoxide dismutase (SOD) mimics for the scavenging of superoxide free radicals $\left(\mathrm{O}_{2}{ }^{-}\right)$during the treatment of diseases of different aetiology and for the protection of healthy tissues was the reason that prompted us to embark on these studies.

In the present work, we report a study on cytoprotective properties of $\left[\mathrm{VO}(\mathrm{ODA})\left(\mathrm{H}_{2} \mathrm{O}\right)_{2}\right],\left[\mathrm{Co}(\mathrm{ODA})\left(\mathrm{H}_{2} \mathrm{O}\right)_{2}\right] \cdot \mathrm{H}_{2} \mathrm{O}$ and $\left[\mathrm{Ni}(\mathrm{ODA})\left(\mathrm{H}_{2} \mathrm{O}\right)_{3}\right] \cdot 1.5 \mathrm{H}_{2} \mathrm{O}$ against the oxidative damage generated exogenously in the Human Dermal Fibroblasts adult (HDFa) cell line as well as their antimicrobial activities against the bacteria (Bacillus subtilis, Escherichia coli, Enterococcus faecalis, Pseudomonas aeruginosa, Staphylococcus aureus, Staphylococcus epidermidis). Furthermore, to get a better insight into physicochemical and biological properties of the complexes, their stability in water and DMSO-water binary systems were investigated. To the best of our knowledge, there are no reports on stabilities of these complexes in the solutions of different physicochemical properties. The obtained results may be helpful for the in-depth understanding of the relationship between physicochemical and biological properties of the complexes under study.

\section{Material and Methods}

Syntheses of the Complexes All reagents used for the syntheses were of analytical grade and were used without further purification. They were as follows: $\mathrm{VO}(\mathrm{acac})_{2}(\geq 98 \%)$, $\mathrm{CoCl}_{2} \cdot 6 \mathrm{H}_{2} \mathrm{O}(\geq 98 \%), \mathrm{NiCl}_{2} \cdot 6 \mathrm{H}_{2} \mathrm{O}(\geq 98 \%)$ and $2,2^{\prime}-$ oxydiacetic acid $\left(\mathrm{H}_{2} \mathrm{ODA}\right)(\geq 98 \%)$. The syntheses of $\left[\mathrm{VO}(\mathrm{ODA})\left(\mathrm{H}_{2} \mathrm{O}\right)_{2}\right],\left[\mathrm{Co}(\mathrm{ODA})\left(\mathrm{H}_{2} \mathrm{O}\right)\right] \cdot \mathrm{H}_{2} \mathrm{O}$ and $\left[\mathrm{Ni}(\mathrm{ODA})\left(\mathrm{H}_{2} \mathrm{O}\right)_{3}\right] \cdot 1.5 \mathrm{H}_{2} \mathrm{O}$ were carried out according to the procedures described in the literature $[13,19]$. The compositions of the compounds were established on the basis of the elemental analysis of carbon and hydrogen (Vario EL analyzer Cube CHNS). Anal. Calcd for [VO $\left.(\mathrm{ODA})\left(\mathrm{H}_{2} \mathrm{O}\right)_{2}\right] \mathrm{C}$, $20,44 \%, \mathrm{H}, 3,44 \%$ : found: C, 20,42\%, H, 3,45\%; $\left[\mathrm{Ni}(\mathrm{ODA})\left(\mathrm{H}_{2} \mathrm{O}\right)_{3}\right] \cdot 1.5 \mathrm{H}_{2} \mathrm{O}: \mathrm{C}, 17.65 \%, \mathrm{H}, 4.83 \%$ : found: $\mathrm{C}, 17.45 \%$, H, $4.79 \%$; [Co(ODA) $\left.\left(\mathrm{H}_{2} \mathrm{O}\right)_{2}\right] \cdot \mathrm{H}_{2} \mathrm{O} \mathrm{C}, 19,60 \%$, $\mathrm{H}, 4.12 \%$; found: $\mathrm{C}, 19,48 \%, \mathrm{H}, 4,10 \%$.
Potentiometric Titrations (PT) Potentiometric titrations were performed in a $30-\mathrm{mL}$ thermostated $(298.15 \pm 0.10 \mathrm{~K})$ cell using the Cerko Lab System microtitration unit fitted with a 5-mL Hamilton's syringe, a pH combined electrode (Schott-BlueLine $16 \mathrm{pH}$ type) and a self-made measuring cell equipped with a magnetic stirrer. The temperature was controlled using the Lauda E100 circulation thermostat. In aqueous solutions, the electrode was calibrated according to IUPAC recommendations [20]. In binary systems $\left(10-50 \% v / v\right.$ DMSO: $\left.\mathrm{H}_{2} \mathrm{O}\right)$, the electrode calibration was performed by the Gran's method [21] using the GLEE program [22]. For this purpose, the $\mathrm{HClO}_{4}$ solution was titrated with tetrabutylammonium hydroxide $\left(\mathrm{Bu}_{4} \mathrm{NOH}\right)$ solution both at the same mole fraction of organic solvent $(10-50(v / v \%)$ DMSO). The syringe was calibrated by a weight method. The double distilled water of conductivity approximately $0.18 \mu \mathrm{S} / \mathrm{cm}$ was used throughout for the preparation of aqueous solutions. Other reagents used in the experiments were purchased from Sigma-Aldrich. They were as follows: $\mathrm{VOSO}_{4}\left(\geq 99.99 \%\right.$ trace metals basis), $\mathrm{Co}\left(\mathrm{NO}_{3}\right)_{2}$. $6 \mathrm{H}_{2} \mathrm{O}$ (ACS reagent, $\geq 99 \%$ ), $\mathrm{Ni}\left(\mathrm{NO}_{3}\right)_{2} \cdot 6 \mathrm{H}_{2} \mathrm{O}(99.999 \%)$ and 2,2'-oxydiacetic acid $\left(\mathrm{H}_{2} \mathrm{ODA}, 98 \%\right)$. All the solutions were prepared immediately before measurements. The compositions of the titrand solutions used in the experiments were as follows: (a) $2 \mathrm{mM} \mathrm{Ni}^{2+}\left(\mathrm{Co}^{2+}\right.$ or $\left.\mathrm{VO}^{2+}\right), 5 \mathrm{mM} \mathrm{H}_{2} \mathrm{ODA}, 5 \mathrm{mM}$ $\mathrm{HClO}_{4}$, (b) $2.5 \mathrm{mM} \mathrm{H}_{2} \mathrm{ODA}$ (for binary systems). The solutions $\left(\mathrm{V}_{\mathrm{o}}=5.0 \mathrm{~mL}\right)$ were potentiometrically titrated with the standardized $0.098 \mathrm{M} \mathrm{NaOH}$ solution or with the standardized $0.025 \mathrm{M}$ $\mathrm{Bu}_{4} \mathrm{NOH}$ solution (in binary systems) in the $\mathrm{pH}$ range from 2.5 to 11.0. The titrant was added to the titrand in increments of $0.01 \mathrm{~mL}$, with a pause of $60 \mathrm{~s}$. Each titration was repeated at least three times in order to check the reproducibility of the data. The stability constants of the complexes were determined using the Hyperquad2008 program [23]. The concentration distribution of various complex species existing in the solution as a function of $\mathrm{pH}$ was obtained using the HySS program [24].

Conductometric Titrations (CT) Conductometric measurements were accomplished on the Cerko Lab System microtitration unit fitted with a 5-mL Hamilton's syringe, a CD-201 conductometric cell with the constant $k=0.096 \mathrm{~cm}^{-1}$ (HYDROMET) and a self-made measuring cell equipped with a magnetic stirrer. The conductometric electrode was standardized with conductivity standards (aqueous $\mathrm{KCl}$ solutions) of conductivity 84 and $200 \mu \mathrm{S} / \mathrm{cm}$, purchased from Hamilton Company. The measurements were carried out at $298.15 \pm$ $0.10 \mathrm{~K}$ controlled by the Lauda E100 circulation thermostat. The titrant $\left(5 \mathrm{mM}\left[\mathrm{Co}(\mathrm{ODA})\left(\mathrm{H}_{2} \mathrm{O}\right)\right]\right.$ or $\left.\left[\mathrm{Ni}(\mathrm{ODA})\left(\mathrm{H}_{2} \mathrm{O}\right)_{3}\right]\right)$ was added to the titrand $\left(0-50 \% v / v\right.$ DMSO- $\left.\mathrm{H}_{2} \mathrm{O}\right)$ both at the same mole fraction of organic solvent, in increments of $0.01 \mathrm{~mL}$, with a pause of $60 \mathrm{~s}$. Each titration was repeated at least three times in order to check the reproducibility of the data. The limiting molar conductance values $\left(\Lambda_{\mathrm{o}}\right)$ and the association constants $\left(\log K_{\text {ass }}\right)$ for the nickel(II) and cobalt(II) 
complexes were computed using the Shedlovsky's [25] and Pitt's [26, 27] method. The physicochemical parameters of the binary solvents used in the calculations were taken from the literature [28-33]. They are collected in Table 1.

The Scavenging of Superoxide Radicals (NBT Method) Nitro blue tetrazolium (NBT, $98 \%$ purity), $\mathrm{KO}_{2}$ ( $96 \%$ purity) and 18-Crown-6 (99\% purity) were purchased from Sigma-Aldrich. The superoxide scavenging activity of the complexes was determined by using their ability to inhibit the reduction of nitro blue tetrazolium (NBT) by superoxide ions. UV-vis measurements were carried out by using the Perkin-Elmer Lambda 650 spectrophotometer equipped with the temperature control-Peltier system with a scan accuracy of 1 and 1$\mathrm{nm}$ slit width. The measurements were carried out in DMSO solution at $288.15 \mathrm{~K}$ according to the method described in the literature [34]. Superoxide free radicals were generated by dissolving 6.5 -mg portion of $\mathrm{KO}_{2}$ powder into DMSO $(50 \mathrm{~mL})$ together with $90 \mathrm{mg}$ of 18 -crown-6-ether. NBT $(10 \mathrm{mg})$ was dissolved directly in DMSO $(10 \mathrm{~mL})$. In general, $1.5 \mathrm{~mL}$ of $\mathrm{DMSO} / \mathrm{KO}_{2} / 18$-crown- 6 mixture was added to $0.5 \mathrm{~mL}$ of the sample to be assayed. The mixture was kept for $20 \mathrm{~min}$ and then $0.1 \mathrm{~mL}$ of NBT solution was added while stirring. The absorbance was monitored spectrophotometrically at $560 \mathrm{~nm}$. The control test was carried out under the same experimental condition under assumption that $\mathrm{KO}_{2}$ and 18crown-6 were absent in DMSO.

The Cell Line and Culture Conditions The Human Dermal Fibroblasts adult (HDFa) cell line (Cascade Biologics) was used in all experiments. Unless otherwise specified, cells were grown in the Dulbecco's modified Eagle's medium (DMEM) supplemented with $10 \%$ fetal bovine serum (FBS) and $1 \times$ antibiotic and antimycotic solutions (all purchased from Sigma) and incubated at $310.15 \mathrm{~K}$ in the humidified $5 \% \mathrm{CO}_{2}$ atmosphere.

The Cytotoxicity Assay HDFa cells were plated at $6 \times 10^{3}$ cells per well in a 96-well tissue culture plate and incubated overnight at $310.15 \mathrm{~K}$ to allow the attachment. The growth medium was substituted with the medium supplemented with tested complex compounds. After 24- or 48-h incubation,

Table 1 The relative permittivity $\varepsilon$, density $\sigma$ and viscosity $\eta$ for DMSOwater mixtures at $298.15 \mathrm{~K}$

\begin{tabular}{llll}
\hline $\operatorname{DMSO}(v / v \%)$ & $\varepsilon$ & $\sigma\left[\mathrm{g} \cdot \mathrm{cm}^{-3}\right]$ & $\eta(\mathrm{mPa} \cdot \mathrm{s})$ \\
\hline 1 & 78.36 & 0.997 & 0.89 \\
10 & 77.75 & 1.011 & 1.07 \\
20 & 76.96 & 1.026 & 1.38 \\
30 & 76.21 & 1.042 & 1.79 \\
40 & 75.45 & 1.057 & 2.35 \\
50 & 74.70 & 1.072 & 3.00 \\
\hline
\end{tabular}

the cell viability was assessed using the MTT solution (3-(4,5-dimethylthiazol-2-yl)-2,5-diphenyltetrazolium bromide [Sigma]) at a concentration of $1 \mathrm{mg} / \mathrm{mL}$ prepared in the RPMI-1640 medium (Sigma). After 2-h incubation at $310.15 \mathrm{~K}$, the amount of purple formazan product, dissolved in dimethylsulfoxide (DMSO) (Sigma), was quantified by measuring the absorbance at $550 \mathrm{~nm}$. The cell viability was calculated as relative to cultures incubated with the medium only (non-treated control), and the $\mathrm{LC}_{25}, \mathrm{LC}_{50}$ and $\mathrm{LC}_{75}$ (lethal concentration for 25,50 and $75 \%$ of cells, respectively) index values were determined from dose-response curves using four parameter logistic equations.

The Proliferation Assay The antiproliferative activity of compounds was assessed using the Cell Proliferation ELISA, BrdU (colorimetric) kit (Roche Applied Science). Cells were seeded at a number of $10^{3}$ cells per well of 96-well tissue culture plate and incubated overnight at $310.15 \mathrm{~K}$. The growth medium was substituted with the medium supplemented with tested compounds, and after 5 days of incubation, labelling with 5-bromo-2'-deoxyuridine (BrdU) was performed for another $24 \mathrm{~h}$. Following steps were performed according to the manufacturer's protocol. The cell proliferation was calculated as relative to cultures incubated with medium only (nontreated control), and the $\mathrm{IC}_{25}, \mathrm{IC}_{50}$ and $\mathrm{IC}_{75}$ (concentrations causing, respectively, 25,50 and $75 \%$ inhibition of cell proliferation) index values were determined from dose-response curves using four parameter logistic equations.

The Determination of Cytoprotective Activity Against the Oxidative Damage Cells were plated at $2 \times 10^{3}$ cells per well of 96-well tissue culture plate. After an overnight incubation, cells were washed with DMEM without FBS and next treated with $1 \mathrm{mM}$ hydrogen peroxide $\left(\mathrm{H}_{2} \mathrm{O}_{2}\right)$ (Sigma) together with different concentrations of tested complex compounds or with $1 \mathrm{mM} \mathrm{H}_{2} \mathrm{O}_{2}$ alone to induce the oxidative damage to cells resulting in the necrotic death. Mixtures were prepared in the growth medium (DMEM) without FBS. Cells treated with the growth medium only were used as a control of normal viability. After 1 -h incubation at $310.15 \mathrm{~K}$, the medium was removed and cells were washed with the growth medium containing $10 \%$ FBS to stop the $\mathrm{H}_{2} \mathrm{O}_{2}$ activity. Next, either the cell viability was assessed using the MTT solution (see previous paragraph) or additional incubation of cells in DMEM containing $10 \% \mathrm{FBS}$ for another $48 \mathrm{~h}$ was performed and then cells were tested for the viability (the MTT assay). The cytoprotective activity of complex compounds against the oxidative damage was calculated relatively to untreated control cells, not exposed to $\mathrm{H}_{2} \mathrm{O}_{2}$.

Bacterial Strains and Culture Media The antimicrobial activity of complex compounds was assessed against Bacillus subtilis, Escherichia coli, Enterococcus faecalis, Pseudomonas 
aeruginosa, Staphylococcus aureus, Staphylococcus epidermidis (all strains were from the collection of the Department of Molecular Biology, University of Gdańsk). All bacteria were cultured in the Luria-Bertani (LB) broth at $310.15 \mathrm{~K}$ in the air with shaking. LB agar plates were prepared by the supplementation of LB broth with the $1.5 \%$ bacteriological agar. Stock solutions of complex compounds were freshly prepared in the LB broth at the concentration of $25 \mathrm{mg} / \mathrm{mL}$.

The Antimicrobial Activity of the Complexes The antimicrobial activity was assessed with the broth dilution method. The LB broth supplemented with the twofold diluted amount of tested compounds (dilution range $1-2048 \mu \mathrm{g} / \mathrm{mL}$ ) was inoculated with $10^{6}$ cfu of bacteria cells per well of 96-well plate. Cultures were incubated at $310.15 \mathrm{~K}$ with shaking for $18-20 \mathrm{~h}$ in the air, and the bacterial growth was estimated by measuring the optical density at $600 \mathrm{~nm}$ with the LB broth as a background control. A minimum inhibitory concentration (MIC) was defined as the lowest concentration of the tested compound (in $\mu \mathrm{g} / \mathrm{mL}$ ) at which there was no visible growth of bacteria compared to the growth observed for the inoculated LB broth without any supplementation. To estimate a minimum bactericidal concentration (MBC), $0.1 \mathrm{~mL}$ of bacterial cultures exhibiting no visible growth were spread on LB agar plates and after an overnight incubation at $310.15 \mathrm{~K}$, the number of colonies was counted. The concentration (in $\mu \mathrm{g} /$ $\mathrm{mL}$ ) at which no colonies were observed was defined as MBC.

The Disc Diffusion Test Aliquots of $0.05 \mathrm{~mL}$ of bacterial culture at the optical density at $600 \mathrm{~nm}$ of 0.1 (inoculum $5 \times$ $10^{6}$ cells per plate) were spread on LB agar plates. Sterile filter paper discs (of $6 \mathrm{~mm}$ diameter) were impregnated with solutions of complex compounds prepared in the deionized water at the following amounts: $0.1,0.2,0.5$ and $1.0 \mathrm{mg}$ per disc and placed on agar plates. After an overnight incubation at $310.15 \mathrm{~K}$, zones of bacterial growth inhibition were measured. Neomycin at the amount of $0.1 \mathrm{mg} /$ disc was used as a control.

\section{Results and Discussion}

The Stability of the Complexes in Water and DMSO-Water Solutions

The equilibrium constants defined by Eqs. (1) and (2):

$\mathrm{pM}+\mathrm{qL}+\mathrm{rH}=\mathrm{M}_{\mathrm{p}} \mathrm{L}_{\mathrm{q}} \mathrm{H}_{\mathrm{r}}$

$\mathrm{pqr}=\frac{\left[\mathrm{M}_{\mathrm{p}} \mathrm{L}_{\mathrm{q}} \mathrm{H}_{\mathrm{r}}\right]}{[\mathrm{M}]^{\mathrm{p}}[\mathrm{L}]^{\mathrm{q}}[\mathrm{H}]^{\mathrm{r}}}$ (where $\mathrm{M}$ is $\mathrm{VO}^{2+}, \mathrm{Co}^{2+}$ or $\mathrm{Ni}^{2+}$, $\mathrm{L}$ denotes the oxydiacetate ion, $\mathrm{H}$ is the proton and $\mathrm{p}, \mathrm{q}, \mathrm{r}$ are stoichiometric coefficients for the reaction) were refined by least-squares calculations using the Hyperquad2008 (version 5.2.19) computer program [20]. For the oxovanadium(IV) system, the formation of the hydroxo complexes of VO(IV) were taken into account in the calculations of the stability constants. The following formation constants were taken from the literature [35] and were fixed: $\log \beta_{10-1}=-5.94, \log \beta_{20-2}=-6.95$ and $\log \beta_{10-3}=-18$. The equilibrium models presented in Table 2 have given the best fitting of the calculated data to the experimental ones. Species distributions as a function of $\mathrm{pH}$ (molar ratio M:L equals 1:1) are shown in Fig. 1.

It has been found that the stability constants of the cobalt(II) and nickel(II) complexes are equal in the range of experimental error but for the oxovanadium(VI) complex, the stability constant is ca. 1 order higher (Table 2). This finding is in agreement with the hard and soft acids and bases (HSAB) theory whereby the oxovanadium(IV) ion as a hard acid forms more stable (thermodynamically) complexes with ligands containing donor atoms of a high electronegativity (such as oxygen atoms in the oxydiacetate ion). Conversely, cobalt(II) and nickel(II) as borderline acids form with the oxydiacetate ions less stable complexes than VO(IV). However, due to the hydroxide competition with the oxydiacetate ion for $\mathrm{VO}(\mathrm{IV})$, the coordination centre easily undergoes a hydrolysis and the resulting hydroxo complex species are formed (Table 2). Thus, in contrary to the $\mathrm{Co}(\mathrm{II})$ and $\mathrm{Ni}(\mathrm{II})$ complexes, $\mathrm{VO}(\mathrm{ODA})$ exists in the narrow range of $\mathrm{pH}$ and above $\mathrm{pH}$ of 5.5 hydroxo species predominate (Fig. 1).

The stability of the complexes under study was tested in the DMSO-water solution containing 0-50\% $(v / v)$ DMSO. The investigation of solvent effects on the stability of the complexes enables to predict their behaviour in the systems of different than pure water physicochemical properties. Besides, the DMSO-water mixture is of a special interest among scientists not only because of its manifold applications as the solvent and reaction media in biology and medicine but also because of its important role in biochemical processes [36-38].

To assess the influence of DMSO as a co-solvent on the stability of the complexes, its effect on the dissociation constants of $\mathrm{H}_{2} \mathrm{ODA}$ was investigated potentiometrically in the first instance. The representative $\mathrm{pH}$-titration curves for oxydiacetic acid at $298.15 \mathrm{~K}$ in 0,30 and $50 \%(v / v)$ DMSO-water binary systems are shown in Fig. 2, whereas the calculated dissociation constants are collected in Table 3 . In the calculations, the ionization constants of the solvents, $\mathrm{p} K_{\mathrm{s}}$, were taken from the literature [39].

As shown in Table 3, the $\mathrm{p} K_{\mathrm{a}}$ 's values of $\mathrm{H}_{2} \mathrm{ODA}$ increase in proportion to the increase of DMSO component in the system. Thus, the protonated species $\left(\mathrm{H}_{2} \mathrm{ODA}\right.$ and $\left.\mathrm{HODA}^{-}\right)$ are becoming more stable (less acidic) as a dielectric constant 
Table 2 Logarithms of the stability constants ( $\log \beta_{\text {pqrs }}$ ) of binary complexes of VO(IV), Co(II) and Ni(II) with oxydiacetate ion (ODA) obtained by adapting the equilibrium model to PT data

\begin{tabular}{llllll}
\hline No. & Species & $\log \beta_{\mathrm{pqr}}$ & $\mathrm{M}=\mathrm{Co}^{2+}$ & $\mathrm{M}^{2+} \mathrm{Ni}^{2+}$ & $\mathrm{M}=\mathrm{VO}^{2+}$ \\
\hline 1 & $\mathrm{LH} 2$ & $\log \beta_{012}$ & $7.26( \pm 0.06)$ & $6.97( \pm 0.01)$ & $7.25( \pm 0.05)$ \\
2 & $\mathrm{LH}$ & $\log \beta_{011}$ & $4.16( \pm 0.09)$ & $4.12( \pm 0.01)$ & $3.20( \pm 0.05)$ \\
3 & $\mathrm{ML}$ & $\log \beta_{110}$ & $3.45( \pm 0.11)$ & $3.52( \pm 0.02)$ & $5.08( \pm 0.04)$ \\
4 & $\mathrm{MLH}-2$ & $\log \beta_{11-2}$ & $-14.88( \pm 0.14)$ & $-14.17( \pm 0.06)$ & $-6.45( \pm 0.04)$ \\
5 & $\mathrm{M}_{2} \mathrm{~L}_{2} \mathrm{H}_{-2}$ & $\log \beta_{22-2}$ & - & - & $1.65( \pm 0.15)$ \\
\hline
\end{tabular}

The standard deviations are given in parenthesis

of a reaction medium is getting lower along with the increase of DMSO content. Generally, it is observed that the stability of the metal complexes increases with the increasing basicity of the ligand [40]. For this reason, the formation of more stable complexes may be expected along with the enrichment of medium in the DMSO component. This assumption has subsequently been verified by studying association constants of the complexes determined from conductometric measurements in DMSO-water mixtures containing 0-50\% $(v / v)$ DMSO. Unfortunately, for the oxovanadium(IV) complex reproducible, reliable data could not been obtained in the binary DMSO-water system due to the too low conductivity of the $\mathrm{VO}(\mathrm{ODA})$ solutions. In the presence of DMSO, the $\mathrm{VO}(\mathrm{ODA})$ complex becomes even more stable than in water and the concentration of species due to its dissociation as well as the concentration of the resulting hydroxo complex are too low to conduct conductometric measurements.

The limiting molar conductance values $\left(\Lambda_{\mathrm{o}}\right)$ and the association constants $\left(\log K_{\text {ass }}\right)$ for the nickel(II) and cobalt(II) complexes were computed using Shedlovsky's [25] and Pitt's $[26,27]$ equations and are consequently collected in Table 4.

The conductometric data have shown that both limiting molar conductance $\left(\Lambda_{\mathrm{o}}\right)$ values and the association constants change approximately linearly with the increase of the amount of DMSO in the system. The dissociation of the complexes takes place to a lesser extent. It manifests itself both in the decrease of molar conductance and in the increase of the association constants. Thus, the neutral complexes of the type $\mathrm{M}(\mathrm{ODA})$ are more stable in media with low dielectric constants (the higher content of DMSO in the system the lower dielectric constant of the medium). At the same time, the solvation of the ionic species by the solvent is becoming less likely and the metal-ligand interactions predominate.

The Reactivity of the Complexes Towards Superoxide Free Radicals

The ability of the complexes to scavenge superoxide anion radicals was evaluated by the NBT assay. The measurements were carried out in the DMSO solution in which $\mathrm{KO}_{2}$ was dissolved via the use of a crown ether to generate superoxide radicals (see Material and Methods).

The plots of the percentage of inhibition versus complex concentrations are presented in Fig. 3. It has been found that all the complexes exhibit the activity towards scavenging of superoxide anions. The results obtained from the NBT assay are in agreement with those obtained earlier by using the $\mathrm{CV}$ method [16]. Both methods have proved that the complexes are capable to scavenge superoxide free radicals. A linear relation was obtained for the cobalt(II) complex (Fig. 3). For the oxovanadium(IV) and nickel(II) complexes, the relationships were found to be non-linear. In that case, the best fitting curves were obtained according to the exponential function described by the equation: $y=y_{0}+\mathrm{A} \cdot \mathrm{e}^{(x / t)}$, where $y$ denoted the percentage of inhibition and $x$ denoted the complex concentration. The differences in the relationships (linear/non-linear) showed in Fig. 3 suggest a different mechanism of scavenging superoxide free radicals. However, the mechanism of the reaction of the complexes with $\mathrm{O}_{2}{ }^{-}$is not easy to elucidate.

The antioxidant activities of the complexes towards $\mathrm{O}_{2}{ }^{-}$ were compared to each other. Based on the obtained relationships (Fig. 3), the complex concentrations causing the $50 \%$ reduction of the concentration of the superoxide ion were calculated. The obtained values were referred to the concentration of ascorbic acid causing the same $\mathrm{O}_{2}{ }^{-}$reduction effect measured at the same experimental conditions. In this way, ascorbic acid equivalents of the complexes were obtained. They are equal $0.35,1.11$ and 4.50 for $\mathrm{VO}(\mathrm{ODA}), \mathrm{Ni}(\mathrm{ODA})$ and $\mathrm{Co}(\mathrm{ODA})$, respectively. The results indicate that reactivity of $\mathrm{VO}(\mathrm{ODA})$ towards superoxide free radicals is higher than for the other two complexes and ascorbic acid used as a standard substance.

The conductometric measurements revealed that the stability of the complexes under study strongly depends on a solvent polarity. In the DMSO solution, the neutral oxydiacetate complexes behave as weak electrolytes and they do not exhibit the tendency to undergo the hydrolysis. Thus, the concentration of free metal ions in the system under study is expected to be very low, and the reactivity of complexes towards superoxide anions in the DMSO solution is mainly governed by the physicochemical properties of the 

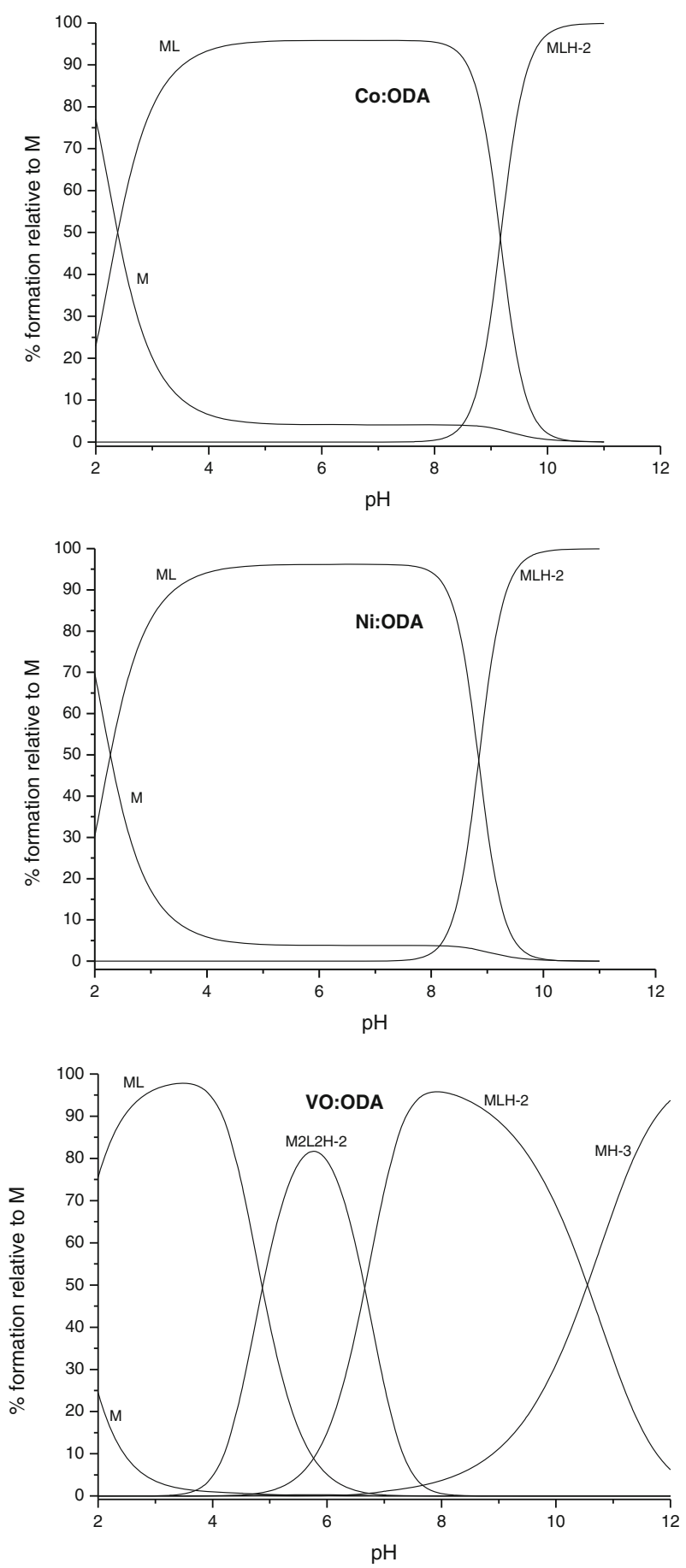

Fig. 1 Concentration distribution curves of the complexes as a function of $\mathrm{pH}(\mathrm{M}: \mathrm{L}=1: 1)$ calculated based on the stability constants listed in Table 2

oxovanadium(IV), cobalt(II) and nickel(II) ions bound to the ODA ligand. To explain the differences in the reactivity of the complexes towards superoxide ions, the ability of the coordination centres of the complexes for undergoing the reduction $\left(\mathrm{M}^{\mathrm{ox}}+\mathrm{O}_{2}{ }^{-}=\mathrm{M}^{\mathrm{red}}+\mathrm{O}_{2}\right)$ as well as the hard/soft-acid/base nature of the resulting species should be taken into account. The oxovanadium(IV) coordination centre has a rather low redox

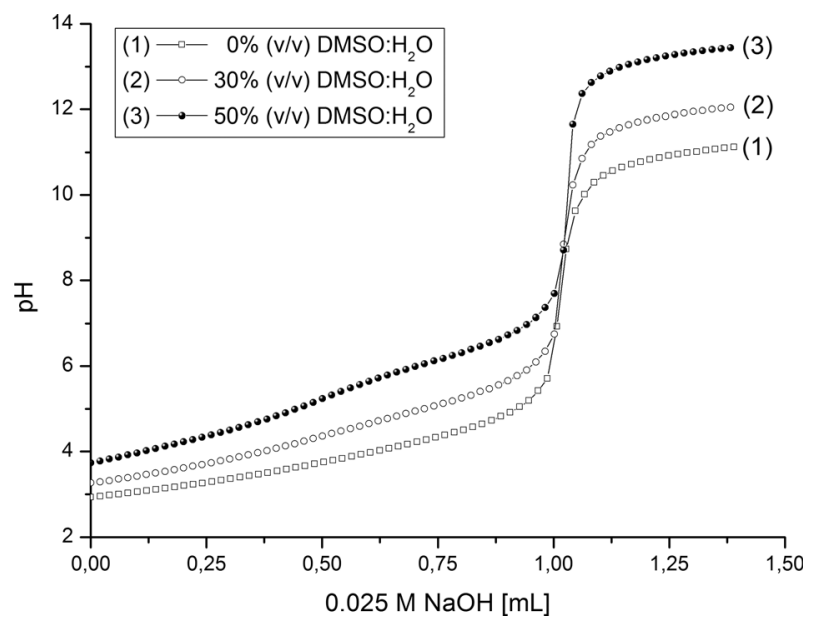

Fig. 2 pH-metric titration curves of $\mathrm{H}_{2} \mathrm{ODA}$ at $298.15 \mathrm{~K}$ in a water, b DMSO-water $30 \%(v / v)$, c DMSO-water $50 \%(v / v)$ binary system

potential ( $\left.\mathrm{V}^{\mathrm{IV}} / \mathrm{V}^{\mathrm{III}}: 0.337 \mathrm{~V}\right)$ and can be reduced to $\mathrm{V}^{\mathrm{III}}[41]$. Furthermore, the ODA ligand, containing hard oxygen donor atoms, has the greater ability to stabilize small hard vanadium(III) ions than the soft $\mathrm{Ni}(\mathrm{I})$ and $\mathrm{Co}(\mathrm{I})$ coordination centres. The reduction of the borderline ions is not favoured in the presence of oxygen donor ligands such as the oxydiacetate anions because they are not suitable for the stabilization of lower oxidation states $\left(\mathrm{M}^{\mathrm{II}}+\mathrm{e}=\mathrm{M}^{\mathrm{I}}\right)$. For this reason, the resulting $\mathrm{Ni}(\mathrm{I})$ and $\mathrm{Co}(\mathrm{I})$ complexes are thermodynamically and kinetically unstable [42]. The above factors are responsible for lower reactivity of cobalt(II) and nickel(II) complexes than $\mathrm{VO}(\mathrm{ODA})$ towards $\mathrm{O}_{2}^{-}$under the experimental conditions.

\section{The Cytotoxicity of the Complexes}

The dose and time-dependent effect of investigated compounds (in the concentration range of $1-500 \mu \mathrm{M}$ ) on a viability of the Human Dermal Fibroblasts adult (HDFa) cell line was tested at the mitochondrial level (MTT test) after 24 and $48 \mathrm{~h}$ of incubation. For nickel(II) and cobalt(II) complexes, no significant cytotoxic effects were observed after $24 \mathrm{~h}$. At the highest concentration of the compounds $(500 \mu \mathrm{M})$, the

Table 3 The dissociation constants of oxydiacetate acid (expressed as $\mathrm{p} K_{\mathrm{a} 1}$ and $\mathrm{p} K_{\mathrm{a} 2}$ ) of different DMSO-water mixtures at $298.15 \mathrm{~K}$

\begin{tabular}{llll}
\hline $\begin{array}{l}\mathrm{DMSO} \\
(\% v / v)\end{array}$ & $\begin{array}{l}\mathrm{p} K_{\mathrm{a} 1} \\
\left(\mathrm{H}_{2} \mathrm{ODA}=\mathrm{HODA}^{-}+\mathrm{H}^{+}\right)\end{array}$ & $\begin{array}{l}\mathrm{p} K_{\mathrm{a} 2} \\
\left(\mathrm{HODA}^{-}=\mathrm{ODA}^{2-}+\mathrm{H}^{+}\right)\end{array}$ & $\mathrm{p} K_{\mathrm{s}}$ \\
\hline 0 & $2.90( \pm 0.05)$ & $4.28( \pm 0.08)$ & 14.0 \\
10 & $3.11( \pm 0.04)$ & $4.52( \pm 0.02)$ & 14.09 \\
20 & $3.28( \pm 0.02)$ & $4.69( \pm 0.02)$ & 14.26 \\
30 & $3.42( \pm 0.04)$ & $4.91( \pm 0.02)$ & 14.40 \\
40 & $3.61( \pm 0.03)$ & $5.16( \pm 0.02)$ & 14.66 \\
50 & $3.76( \pm 0.03)$ & $5.46( \pm 0.03)$ & 14.82 \\
\hline
\end{tabular}

The standard deviations are given in parenthesis 
Table 4 The limiting molar conductance $\left(\Lambda_{\mathrm{o}}\right)$ values in $\mathrm{S} \mathrm{cm}^{2} \mathrm{~mol}^{-1}$ and the association constants $\left(\log K_{\text {ass }}\right)$ of the oxydiacetate cobalt(II) and nickel(II) complexes in DMSO-water mixtures at $298.15 \mathrm{~K}$

\begin{tabular}{|c|c|c|c|c|c|c|c|}
\hline \multirow[t]{2}{*}{ Method } & \multirow[t]{2}{*}{ Parameter } & \multicolumn{6}{|c|}{ DMSO-water $(\% v / v)$} \\
\hline & & 0 & 10 & 20 & 30 & 40 & 50 \\
\hline \multicolumn{8}{|l|}{ NiODA } \\
\hline \multirow[t]{2}{*}{ Shedlovsky } & $\Lambda_{\mathrm{o}}$ & $216.10( \pm 0.74)$ & $161.00( \pm 0.95)$ & $119.83( \pm 0.83)$ & $90.63( \pm 1.37)$ & $51.85( \pm 0.61)$ & $28.80( \pm 0.48)$ \\
\hline & $\log K_{\text {ass }}$ & $3.33( \pm 0.01)$ & $3.47( \pm 0.01)$ & $3.59( \pm 0.01)$ & $3.74( \pm 0.01)$ & $4.05( \pm 0.02)$ & $4.15( \pm 0.03)$ \\
\hline \multirow[t]{2}{*}{ Pitts } & $\Lambda_{\mathrm{o}}$ & $216.74( \pm 1.08)$ & $161.75( \pm 0.93)$ & $114.72( \pm 1.55)$ & $91.35( \pm 1.33)$ & $52.00( \pm 0.50)$ & $29.49( \pm 0.92)$ \\
\hline & $\log K_{\text {ass }}$ & $3.34( \pm 0.01)$ & $3.48( \pm 0.01)$ & $3.56( \pm 0.01)$ & $3.75( \pm 0.01)$ & $4.05( \pm 0.01)$ & $4.17( \pm 0.04)$ \\
\hline \multicolumn{8}{|l|}{ CoODA } \\
\hline \multirow[t]{2}{*}{ Shedlovsky } & $\Lambda_{\mathrm{o}}$ & $223.49( \pm 1.45)$ & $171.55( \pm 0.74)$ & $133.47( \pm 1.00)$ & $92.16( \pm 1.07)$ & $55.24( \pm 0.84)$ & $28.52( \pm 1.58)$ \\
\hline & $\log K_{\text {ass }}$ & $3.35( \pm 0.01)$ & $3.49( \pm 0.01)$ & $3.77( \pm 0.01)$ & $3.89( \pm 0.01)$ & $4.09( \pm 0.03)$ & $4.22( \pm 0.02)$ \\
\hline \multirow[t]{2}{*}{ Pitts } & $\Lambda_{\mathrm{o}}$ & $226.58( \pm 1.32)$ & $173.97( \pm 0.60)$ & $134.29( \pm 1.09)$ & $92.53( \pm 0.96)$ & $57.02( \pm 0.71)$ & $29.74( \pm 1.46)$ \\
\hline & $\log K_{\text {ass }}$ & $3.38( \pm 0.01)$ & $3.51( \pm 0.01)$ & $3.77( \pm 0.01)$ & $3.89( \pm 0.01)$ & $4.05( \pm 0.01)$ & $4.32( \pm 0.03)$ \\
\hline
\end{tabular}

viability of the cells was no less than $95 \%$. An extension of the exposure time from 24 to $48 \mathrm{~h}$ triggers a slight decrease in the viability of the cells to about 90 and $75 \%$ for the $\mathrm{Co}(\mathrm{II})$ and $\mathrm{Ni}(\mathrm{II})$ complex at $500 \mu \mathrm{M}$, respectively. It is interesting to note that only the oxovanadium(IV) complex exhibits the cytotoxic effect on fibroblast cells in the tested concentration range after $24 \mathrm{~h}$ of incubation and its cytotoxic activity increases in proportion to the exposure time. The cytotoxic properties of the complexes under study, expressed as lethal concentration $\left(\mathrm{LC}_{25}, \mathrm{LC}_{50}\right.$ and $\left.\mathrm{LC}_{75}\right)$ values, are summarized in Table 5.

\section{The Antiproliferative Activity of the Complexes}

The dose-dependent (in the concentration range of 1 $1000 \mu \mathrm{M}$ ) effect of the complexes on the HDFa cell proliferation was investigated by the measurement of BrdU (5-bromo-2'-deoxyuridine) incorporation by actively dividing cells after 6 days of culture in the presence of different

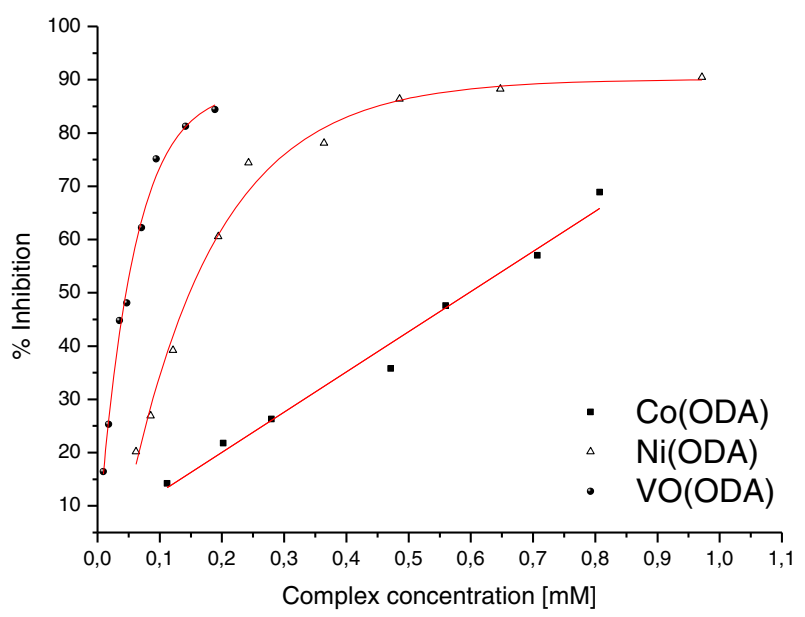

Fig. 3 The superoxide free radicals scavenging activity of the complexes concentrations of complexes (Fig. 4). Based on the obtained data, inhibitory concentrations $\left(\mathrm{IC}_{25}, \mathrm{IC}_{50}\right.$ and $\left.\mathrm{IC}_{75}\right)$ for each compound were calculated and they are summarized in Table 6 . The highest antiproliferative activity was found for oxovanadium(IV) complex $\left(\mathrm{IC}_{50}=25 \mu \mathrm{M}\right)$. At higher concentrations, the synergy effect, connected with the increase of the $\mathrm{VO}(\mathrm{ODA})$ cytotoxicity with the exposure time, on the antiproliferative activity was observed. The $\mathrm{Co}(\mathrm{II})$ and $\mathrm{Ni}$ (II) complexes exhibit the antiproliferative activity comparable to each other, and they cause the $50 \%$ inhibition of cell proliferation at ca. $200 \mu \mathrm{M}$.

The Cytoprotective Activity of the Complexes Against Oxidative Damage

To induce a cellular injury in the HDFa cell line and assess the cytoprotective activity of the complexes, the oxidative damage was generated exogenously by using hydrogen peroxide, $\mathrm{H}_{2} \mathrm{O}_{2}$. It is worth noticing that the activity of $\mathrm{H}_{2} \mathrm{O}_{2}$ as an

Table 5 The cytotoxic activity of VO(ODA), Co(ODA) and Ni(ODA) against the HDFa cell line expressed as the lethal concentration (LC) values $(\mu \mathrm{M})$ after $24 \mathrm{~h}$ and $48 \mathrm{~h}$ of incubation (MTT test)

\begin{tabular}{clll}
\hline & NiODA & CoODA & VOODA \\
\hline 24-h exposure time & & & \\
$\mathrm{LC}_{25}[\mu \mathrm{M}]$ & Immeasurable & Immeasurable & 108.03 \\
$\mathrm{LC}_{50}[\mu \mathrm{M}]$ & Immeasurable & Immeasurable & 295.74 \\
$\mathrm{LC}_{75}[\mu \mathrm{M}]$ & Immeasurable & Immeasurable & 560.17 \\
48-h exposure time & & & \\
$\mathrm{LC}_{25}[\mu \mathrm{M}]$ & 492.04 & Immeasurable & 27.03 \\
$\mathrm{LC}_{50}[\mu \mathrm{M}]$ & 1309.71 & Immeasurable & 87.45 \\
$\mathrm{LC}_{75}[\mu \mathrm{M}]$ & 2339.01 & Immeasurable & 180.53 \\
\hline
\end{tabular}

LC values $(\mu \mathrm{M})$ were estimated from dose-response curves using fourparameter logistic equations 


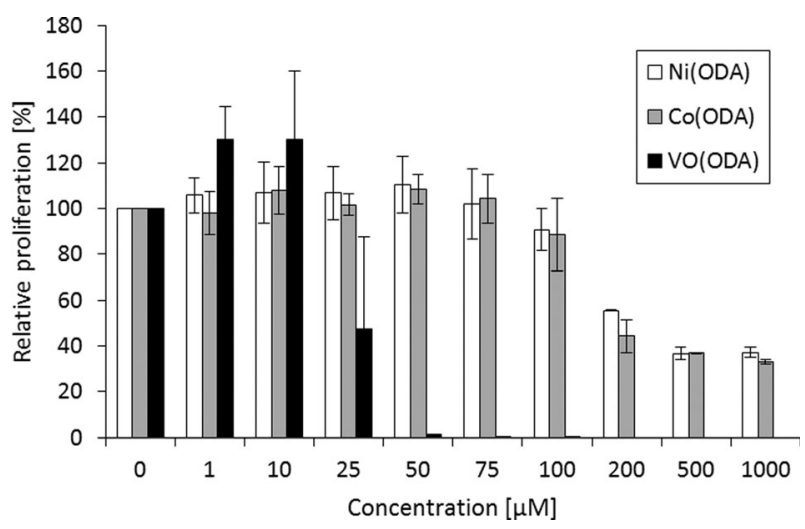

Fig. 4 The influence of $\mathrm{VO}(\mathrm{ODA}), \mathrm{Ni}(\mathrm{ODA})$ and $\mathrm{Co}(\mathrm{ODA})$ on the relative proliferation of HDFa cells after 6 days of exposure to investigated complex compounds (based on 24-h BrdU incorporation by actively dividing cells). Values represent means of four different experiments (run in duplicate) $\pm \mathrm{SD}$

oxidative damage-inducing factor was governed by the concentration of fetal bovine serum FBS in the cell culture medium, thus, $1 \mathrm{mM} \mathrm{H}_{2} \mathrm{O}_{2}$ in growth medium without FBS was used for the induction of oxidative damage resulting in the cellular death to about $80 \%$ of cells after 1-h exposure.

Screening of cytoprotective properties of $\mathrm{VO}(\mathrm{IV}), \mathrm{Ni}(\mathrm{II})$ and $\mathrm{Co}(\mathrm{II})$ complexes has shown that $\mathrm{Co}(\mathrm{ODA})$ exhibits the highest dose- and time-dependent protective effect against the oxidative damage. The results of the MTT test (Figs. 5 and 6) revealed that the viability of human fibroblasts treated with $1 \mathrm{mM} \mathrm{H}_{2} \mathrm{O}_{2}$ together with the complex for $1 \mathrm{~h}$ increases in proportion to the amount of $\mathrm{Co}(\mathrm{ODA})$ in the system (Fig. 5). The viability of cells increases up to ca. $100 \%$ in the case of treatment with $500 \mu \mathrm{M} \mathrm{Co}(\mathrm{ODA})$ and is comparable to the untreated cells (Fig. 5). The ability of cells, first exposed to $\mathrm{H}_{2} \mathrm{O}_{2}$ and $\mathrm{Co}(\mathrm{ODA})$, to grow and proliferate at similar levels to untreated control cells after an additional 48-h incubation in the normal growth medium, confirms the cytoprotective activity of this complex against the oxidative damage (Fig. 6). Interestingly, also $\mathrm{VO}(\mathrm{ODA})$, to some extent, exhibits the cytoprotective activity against the oxidative damage to cells at the short, 1-h exposure time (Fig. 5), but due to its strong

Table 6 The antiproliferative activity of the VO(ODA), Ni(ODA) and $\mathrm{Co}(\mathrm{ODA})$ complexes against HDFa cells after 6 days of exposure to investigated complex compounds (based on the 24-h BrdU incorporation by actively dividing cells)

6 day-exposure time

\begin{tabular}{lccc}
\hline & $\mathrm{Ni}(\mathrm{ODA})$ & $\mathrm{Co}(\mathrm{ODA})$ & $\mathrm{VO}(\mathrm{ODA})$ \\
\hline $\mathrm{IC}_{25}(\mu \mathrm{M})$ & 148.65 & 128.90 & 23.41 \\
$\mathrm{IC}_{50}(\mu \mathrm{M})$ & 219.97 & 175.08 & 24.86 \\
$\mathrm{IC}_{75}(\mu \mathrm{M})$ & $>1000$ & $>1000$ & 26.42 \\
\hline
\end{tabular}

IC values $(\mu \mathrm{M})$ were estimated from dose-response curves using fourparameter logistic equations

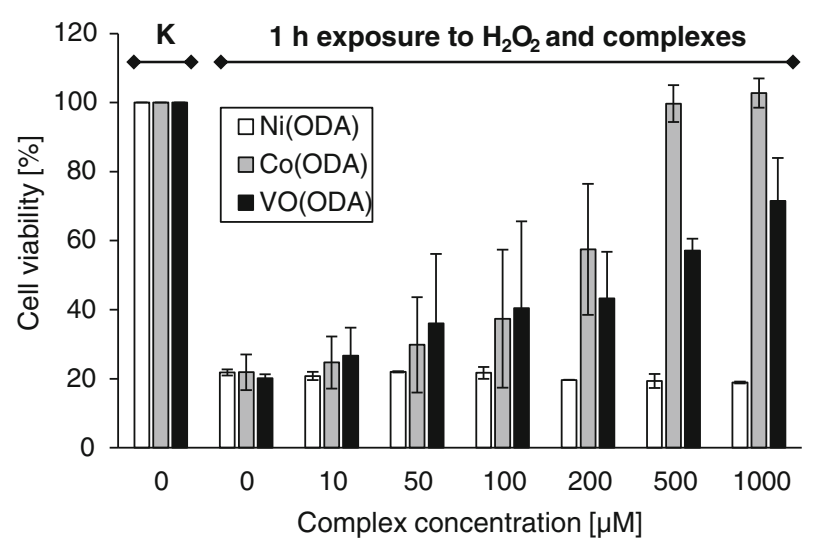

Fig. 5 The viability of the HDFa cells after a 1-h incubation in the presence of $1 \mathrm{mM} \mathrm{H}_{2} \mathrm{O}_{2}$ and different concentrations of investigated complex compounds. $K$ denotes cells not treated with $\mathrm{H}_{2} \mathrm{O}_{2}$ nor complexes (control cells). Values represent means of three different experiments (run in triplicate) $\pm \mathrm{SD}$

cytotoxic activity, $\mathrm{VO}(\mathrm{ODA})$ itself induces the cell death and the effect is visible after the additional 48-h incubation of cells in the growth medium (Fig. 6). A different situation is seen for the $\mathrm{Ni}(\mathrm{ODA})$ complex. It has no influence on the viability of cells, regardless of the dose used together with $\mathrm{H}_{2} \mathrm{O}_{2}$ (Figs. 5 and 6).

The Antimicrobial Activity of the Complexes

The antimicrobial activity of the complexes studied was evaluated against following bacteria species: Bacillus subtilis, Escherichia coli, Enterococcus faecalis, Pseudomonas aeruginosa, Staphylococcus aureus and Staphylococcus epidermidis. The minimum inhibitory concentrations (MICs) were determined for each complex based on the change of the optical density of bacterial cultures grown over the complex concentration range $1-2048 \mu \mathrm{g} / \mathrm{mL}$ (Table 7). The study revealed that all complexes inhibit the growth of bacteria

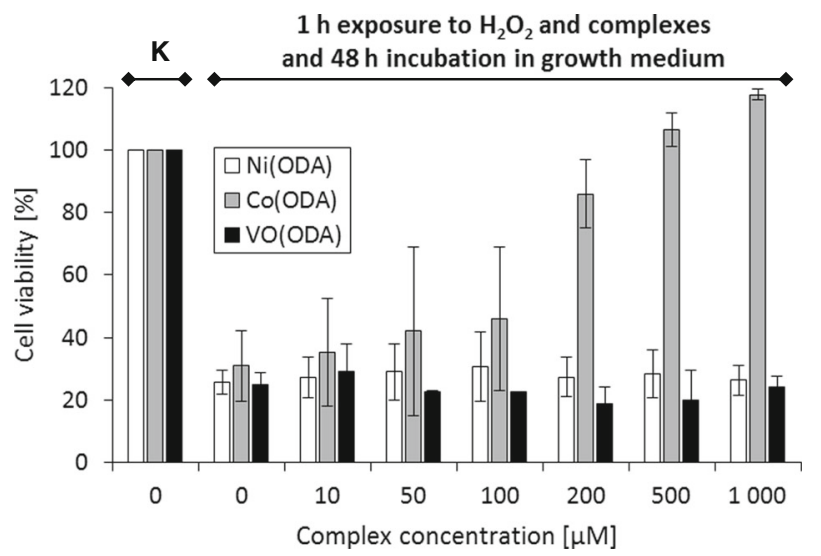

Fig. 6 The viability of HDFa cells after an additional 48-h incubation in the growth medium following a 1-h incubation in the presence of $1 \mathrm{mM}$ $\mathrm{H}_{2} \mathrm{O}_{2}$ and different concentrations of investigated complex compounds. $K$ denotes cells not treated with $\mathrm{H}_{2} \mathrm{O}_{2}$ nor complexes (control cells). Values represent means of three different experiments (run in triplicate) $\pm \mathrm{SD}$ 
Table 7 MIC and MBC values $(\mu \mathrm{g} / \mathrm{mL})$ for the complexes obtained in the broth dilution test

\begin{tabular}{|c|c|c|c|c|c|c|}
\hline \multirow[t]{2}{*}{ Bacteria } & \multicolumn{2}{|c|}{$\mathrm{Ni}(\mathrm{ODA})(\mu \mathrm{g} / \mathrm{mL})$} & \multicolumn{2}{|c|}{$\mathrm{Co}(\mathrm{ODA})(\mu \mathrm{g} / \mathrm{mL})$} & \multicolumn{2}{|c|}{$\mathrm{VO}(\mathrm{ODA})(\mu \mathrm{g} / \mathrm{mL})$} \\
\hline & MIC & $\mathrm{MBC}$ & MIC & $\mathrm{MBC}$ & MIC & MBC \\
\hline B. subtilis & 512 & - & 256 & - & 2048 & - \\
\hline E. coli & 1024 & - & 512 & 1024 & 2048 & - \\
\hline E. faecalis & 1024 & - & 256 & - & 1024 & 1024 \\
\hline P. aeruginosa & 1024 & - & 256 & - & 1024 & - \\
\hline S. aureus & 1024 & - & 256 & 512 & 1024 & 2048 \\
\hline S. epidermidis & 512 & 2048 & 256 & 2048 & 2048 & 2048 \\
\hline
\end{tabular}

under study, but their activity depends on the complex concentration. The highest antimicrobial activity was found for the $\mathrm{Co}(\mathrm{ODA})$ complex.

To assess whether the antimicrobial activity of complexes was bacteriostatic or bactericidal, for each culture medium, where no visible growth was observed, the number of bacteria colonies formed on LB plates was counted after an overnight incubation at $310.15 \mathrm{~K}$. MBC values were estimated and the results are summarized in Table 7 . The complexes exhibit the bacteriostatic activity against most of bacterial strains. Furthermore, the bactericidal activity against $S$. epidermidis has been found for $\mathrm{Ni}(\mathrm{ODA})$. The $\mathrm{Co}(\mathrm{ODA})$ complex shows the bactericidal activity against $E$. coli, S. aureus and $S$. epidermidis whereas VO(ODA) against E. faecalis, $S$. aureus and $S$. epidermidis.

Zones of inhibition of bacterial growth for investigated complexes are listed in Table 8. The most effective values were obtained for $\mathrm{Co}(\mathrm{ODA})$ at the amount of $1000 \mu \mathrm{g}$ per disc, and the activity of this complex was similar to that of $100 \mu \mathrm{g}$ of neomycin against all tested bacteria strains except B. subtilis. Ni(ODA) showed some activity against $B$. subtilis and $S$. epidermidis and VO(ODA) against $B$. subtilis, $E$. faecalis and $S$. epidermidis, but in both cases, zones of inhibition were lower comparing to $\mathrm{Co}(\mathrm{ODA})$.

\section{Conclusions}

The potentiometric and conductometric titration methods have successfully been applied to characterize the stability of the oxydiacetate complexes of oxovanadium(IV), cobalt(II) and nickel(II) in the dimethylsulfoxide (DMSO)-water $\left(\mathrm{H}_{2} \mathrm{O}\right)$ binary mixtures.

The stability constant values for the complexes studied increase in the sequence $\mathrm{Co}(\mathrm{ODA}) \approx \mathrm{Ni}(\mathrm{ODA})<\mathrm{VO}(\mathrm{ODA})$. This finding is in a good agreement with the classification of the donor-acceptor atoms based on the HSAB theory. A softer character of $\mathrm{Co}(\mathrm{II})$ and $\mathrm{Ni}$ (II) with respect to $\mathrm{VO}(\mathrm{IV})$ results in the formation of less stable complexes with the ligands containing hard donor atoms. On the other hand, the cobalt(II) and nickel(II) complexes, in contrary to VO(ODA), are stable in a much broader $\mathrm{pH}$ range. Furthermore, conductometric measurements reveal that the stability of the complexes increases in proportion to the amount of DMSO in the system. Thus, in media with low dielectric constants, the complexes behave as weak electrolytes.

Based on the NBT assay, it has been found that all the complexes studied are capable to scavenge the superoxide free radical. Their reactivity towards $\mathrm{O}_{2}{ }^{-}$is governed by the ability of the ligand to stabilize the lower oxidation states of the

Table 8 Zones of complete bacterial growth inhibition $(\mathrm{mm})$ for complexes obtained in the disc diffusion test

\begin{tabular}{|c|c|c|c|c|c|c|c|c|c|c|}
\hline \multirow[t]{4}{*}{ Bacteria } & \multicolumn{10}{|c|}{ Zone of growth inhibition (mm) } \\
\hline & \multirow{2}{*}{\multicolumn{3}{|c|}{$\frac{\mathrm{Ni}(\mathrm{ODA})}{(\mu \mathrm{g} / \mathrm{disc})}$}} & \multicolumn{3}{|c|}{$\mathrm{Co}(\mathrm{ODA})$} & \multicolumn{3}{|c|}{$\mathrm{VO}(\mathrm{ODA})$} & \multirow[t]{2}{*}{$\mathrm{Neo}$} \\
\hline & & & & & & & & & & \\
\hline & 100 & 500 & 1000 & 100 & 500 & 1000 & 100 & 500 & 1000 & 100 \\
\hline B. subtilis & - & 8 & 8 & - & 9 & 11 & - & - & 7 & 21 \\
\hline E. coli & - & - & - & - & 12 & 14 & - & - & - & 15 \\
\hline E. faecalis & - & - & - & - & 10 & 15 & - & 9 & 13 & 16 \\
\hline P. aeruginosa & - & - & - & - & 14 & 18 & - & - & - & 17 \\
\hline S. aureus & - & 7 & 8 & 7 & 12 & 17 & - & - & - & 18 \\
\hline S. epidermidis & - & - & - & 8 & 19 & 23 & - & - & 12 & 25 \\
\hline
\end{tabular}

Neomycin (Neo) was used as a control 
coordination centre. For this reason, VO(ODA) has been found to show the highest superoxide dismutase (SOD) activity.

The cytoprotective activity of the complexes against the oxidative damage of fibroblast cells generated by hydrogen peroxide strongly depends on the kind of the coordination centre of the complex. The cobalt(II) complex has been found to show the highest cytoprotective activity in contrast to the nickel(II) complex that does not exhibit cytoprotective activity, regardless of the dose used. Unexpectedly, VO(ODA) has been found to exhibit the cytotoxic activity on fibroblast cells. However, the oxovanadium(IV) complex exhibits the cytoprotective activity against the oxidative damage to cells at a short time, but due to its cytotoxic effect itself induces the cell death after further exposure.

The oxovanadium(IV), cobalt(II) and nickel(II) complexes studied inhibit the growth of bacteria under study. The highest antimicrobial activity is revealed by the $\mathrm{Co}(\mathrm{ODA})$ complex.

Acknowledgments This research was supported by the National Science Centre (grant 2011/03/D/ST5/05920).

Open Access This article is distributed under the terms of the Creative Commons Attribution License which permits any use, distribution, and reproduction in any medium, provided the original author(s) and the source are credited.

\section{References}

1. O'Keeffe M, Yaghi OM (2012) Deconstructing the crystal structures of metal organic frameworks and related materials into their underlying nets. Chem Rev 112:675-702

2. Sharples JW, Collison D (2014) The coordination chemistry and magnetism of some $3 \mathrm{~d}-4 \mathrm{f}$ and $4 \mathrm{f}$ amino-polyalcohol compounds. Coord Chem Rev 260:1-20

3. Bambagioni V et al (2008) Polyamine-polycarboxylate metal complexes with different biological effectiveness as nitric oxide scavengers. Clues for drug design. J Med Chem 51:3250-3260

4. Failli $\mathrm{P}$ et al (2009) A novel manganese complex effective as superoxide anion scavenger and therapeutic agent against cell and tissue oxidative injury. J Med Chem 52:7273-7283

5. León IE, Butenko N, Di Virgilio AL, Muglia CI, Baran EJ, Cavaco I, Etcheverry SB (2014) Vanadium and cancer treatment: antitumoral mechanisms of three oxidovanadium(IV) complexes on a human osteosarcoma cell line. J Inorg Biochem 134:106-117

6. Álvarez L, Grirrane A, Moyano R, Álvarez E, Pastor A, Galindo A (2010) Comparison of the coordination capabilities of thiodiacetate and oxydiacetate ligands through the $\mathrm{X}$-ray characterization and DFT studies of $[\mathrm{V}(\mathrm{O})(\mathrm{tda})(\mathrm{phen})] \cdot 4 \mathrm{H} 2 \mathrm{O}$ and $[\mathrm{V}(\mathrm{O})($ oda $)($ phen $)] \cdot 1.5 \mathrm{H} 2 \mathrm{O}$. Polyhedron 29:3028-3035

7. Baggio R, Garland MT, Perec M (1996) Synthesis and characterization of zinc(II) oxydiacetate (oda) complexes. Crystal structures of $[\{\mathrm{Zn}($ oda $) \cdot 0.3 \mathrm{H} 2 \mathrm{O}\} \mathrm{n}],[\mathrm{Zn}$ (oda)(bipy) $(\mathrm{H} 2 \mathrm{O})] \cdot 2.5 \mathrm{H} 2 \mathrm{O}$ and $\left[\mathrm{Zn}\right.$ (oda)(phen)(H2O)] $1.5 \mathrm{H} 2 \mathrm{O}$ (bipy $=2,2^{\prime}$-bipyridine, phen $=1,10$ phenanthroline). J Chem Soc, Dalton Trans 2747-2753.

8. Dai JC et al (2004) Crystal engineering of the coordination architecture of metal polycarboxylate complexes by hydrothermal synthesis: assembly and characterization of four novel cadmium polycarboxylate coordination polymers based on mixed ligands. Eur J Inorg Chem 2004:2096-2106

9. Jiang C, Wang ZY (2003) Synthesis, structure and interconversion of two $\mathrm{Co}$ (II) coordination polymers showing topological isomerism from 1D chain to 3D chiral network. Polyhedron 22:2953-2959

10. Hou GF, Li HX, Li WZ, Yan PF, Su XH, Li GM (2013) Two series of luminescent flexible polycarboxylate lanthanide coordination complexes with double layer and rectangle metallomacrocycle structures. Cryst Growth Des 13:3374-3380

11. Grirrane A, Pastor A, Álvarez E, González M, Galindo A (2007) Synthesis of mixed cobalt-nickel oxydiacetate compounds: the X-ray characterization of $\left[\mathrm{Co}_{0.4} \mathrm{Ni}_{0.6}(\mathrm{oda})\left(\mathrm{H}_{2} \mathrm{O}\right)_{3}\right] \cdot 1.5 \mathrm{H}_{2} \mathrm{O}$. Polyhedron 26 : 3343-3349

12. Grirrane A, Pastor A, Álvarez E, Mealli C, Ienco A, Rosa P, Galindo A (2007) Thiodiacetate and oxydiacetate cobalt complexes: synthesis, structure and stereochemical features. Eur J Inorg Chem 3543-3552

13. Grirrane A, Pastor A, Ienco A, Mealli C, Galindo A (2002) Synthesis and molecular structure of oxydiacetate complexes of nickel(II) and cobalt(II). Theoretical analysis of the planar and non-planar conformations of oxydiacetate ligand and oxydiacetic acid. J Chem Soc, Dalton Trans 3771-3777

14. Siddiqi ZA, Sharma PK, Shahid M, Khalid M, Kumar S (2011) Synthesis, spectral characterizations and biological studies of transition metal mixed ligand complexes: X-ray crystal structures of $\left[\mathrm{Cu}\left(\right.\right.$ oda)(Bipy)(H2O)] $4 \mathrm{H} 2 \mathrm{O}$ and [VO(oda)(Bipy)] $2 \mathrm{H}_{2} \mathrm{O}$. J Mol Struct 994:295-301

15. Siddiqi ZA, Sharma PK, Shahid M, Khalid M, Anjuli SA, Kumar S (2012) Superoxide scavenging and antimicrobial activities of novel transition metal complexes of oxydiacetate dianion as primary ligand: spectral characterization, cyclic voltammetric investigations and crystal structure. Eur J Med Chem 57:102-111

16. Wyrzykowski D et al (2013) Electrochemical and biological studies on reactivity of $\left[\mathrm{VO}(\right.$ oda $\left.)\left(\mathrm{H}_{2} \mathrm{O}\right)_{2}\right],\left[\mathrm{Co}(\right.$ oda $\left.)\left(\mathrm{H}_{2} \mathrm{O}\right)_{2}\right] \cdot \mathrm{H}_{2} \mathrm{O}$, and $\left[\mathrm{Ni}\right.$ (oda) $\left.\left(\mathrm{H}_{2} \mathrm{O}\right)_{3}\right] \cdot 1.5 \mathrm{H}_{2} \mathrm{O}$ towards superoxide free radicals. $\mathrm{Z}$ Anorg Allg Chem 639:1795-1799

17. Wyrzykowski D, Anusiewicz I, Pilarski B, Jacewicz D, Chmurzyński L (2013) Investigations of coordinating properties of oxydiacetate and thiodiacetate anions towards $\mathrm{Zn}^{2+}$ ions in solutions. Inorg Chim Acta 405:163-168

18. Wyrzykowski D, Pranczk J, Jacewicz D, Tesmar A, Pilarski B, Chmurzyński L (2014) Investigations of ternary complexes of $\mathrm{Co}(\mathrm{II})$ and $\mathrm{Ni}(\mathrm{II})$ with oxydiacetate anion and 1,10-phenanthroline or 2,2'-bipyridine in solutions. Cent Eur J Chem 12:107-114

19. Del Río D, Galindo A, Tejedo J, Bedoya FJ, Ienco A, Mealli C (2000) Synthesis, antiapoptotic biological activity and structure of an oxovanadium (IV) complex with an OOO ligand donor set. Inorg Chem Commun 3:32-34

20. Brandariz I, Barriada J, Vilarino T, de Vicente MS (2004) Comparison of several calibration procedures for glass electrodes in proton concentration. Monatsh Chem 135:1475-1488

21. Gran G (1952) Determination of the equivalence point in potentiometric titrations. Part II. Analyst 77:661-671

22. Gans P, O’Sullivan B (2000) GLEE, a new computer program for glass electrode calibration. Talanta 51:33-37

23. Gans P, Sabatini A, Vacca A (1996) Investigation of equilibria in solution. Determination of equilibrium constants with the HYPERQUAD suite of programs. Talanta 43:1739-1753

24. Alderighi L, Gans P, Ienco A, Peters D, Sabatini A, Vacca A (1999) Hyperquad simulation and speciation (HySS): a utility program for the investigation of equilibria involving soluble and partially soluble species. Coord Chem Rev 184:311-318

25. Radhika V, Srinivas N, Manikyamba P (2012) Ion association and solvation behavior of nicotinium dichromate in water-N, N-dimethyl formamide mixtures by a conductometric study. Eur J Chem 3:71-74

26. Pitts E, Tabor BE, Daly J (1970) Concentration dependence of electrolyte conductance. Part 2.-comparison of experimental data 
with the Fuoss-Onsager and Pitts treatments. Trans Faraday Soc 66: 693-707

27. Pitts E, Tabor BE, Daly J (1969) Concentration dependence of electrolyte conductance. Part 1.-Comparison of the FuossOnsager and Pitts treatments. Trans Faraday Soc 65:849-862

28. Srivastava AK, Shankar SL (2000) Ionic conductivity in binary solvent mixtures. 4. Dimethyl sulfoxide + water at $25^{\circ} \mathrm{C}$. J Chem Eng Data 45:92-95

29. LeBel RG, Goring DAI (1962) Density, viscosity, refractive index, and hygroscopicity of mixtures of water and dimethyl sulfoxide. J Chem Eng Data 7:100-101

30. Puranik SM, Kumbharkhane AC, Mehrotra SC (1992) Dielectric study of dimethyl sulfoxide-water mixtures using the time-domain technique. J Chem Soc Faraday Trans 88:433-435

31. Kaatze U, Pottel R, Schäfer M (1989) Dielectric spectrum of dimethyl sulfoxide/water mixtures as a function of composition. J Phys Chem 93:5623-5627

32. Yang LJ, Yang XQ, Huang KM, Jia GZ, Shang H (2009) Dielectric properties of binary solvent mixtures of dimethyl sulfoxide with water. Int J Mol Sci 10:1261-1270

33. Cowie JMG, Toporowski PM (1961) Association in the binary liquid system dimethyl sulphoxide - water. Can J Chem 39:2240-2243

34. Liu R, Fu S, Zhan H, Lucia LA (2009) General spectroscopic protocol to obtain the concentration of the superoxide anion radical. Ind Eng Chem Res 48:9331-9334

35. Henry RP, Mitchell PCH, Prue JE (1973) Hydrolysis of the oxovanadium(IV) ion and the stability of its complexes with the 1 , 2-dihydroxybenzenato(2-) ion. J Chem Soc Dalton Trans 1156-1159
36. Catalán J, Díaz C, García-Blanco F (2001) Characterization of binary solvent mixtures of DMSO with water and other cosolvents. J Org Chem 66:5846-5852

37. Mancera RL, Chalaris M, Refson K, Samios J (2004) Molecular dynamics simulation of dilute aqueous DMSO solutions. A temperature-dependence study of the hydrophobic and hydrophilic behaviour around DMSO. Phys Chem Chem Phys 6:94-102

38. Pawlak Z, Bates RG (1975) Solute-solvent interactions in acid-base dissociation: nine protonated nitrogen bases in water-DMSO solvents. J Solut Chem 4:817-829

39. Farjtabar A (2012) Application of electrochemistry to determination of transfer Gibbs energies and autoprotolysis constants for aqueous mixtures of dimethyl sulfoxide. J Appl Chem Res 1: $28-35$

40. Barszcz B (2005) Coordination properties of didentate N, O heterocyclic alcohols and aldehydes towards $\mathrm{Cu}(\mathrm{II}), \mathrm{Co}(\mathrm{II}), \mathrm{Zn}$ (II) and $\mathrm{Cd}(\mathrm{II})$ ions in the solid state and aqueous solution. Coord Chem Rev 249:2259-2276

41. Islam MK, Tsuboya C, Kusaka H, Aizawa S, Ueki T (2007) Reduction of vanadium(V) to vanadium(IV) by NADPH, and vanadium(IV) to vanadium(III) by cysteine methyl ester in the presence of biologically relevant ligands. Biochim Biophys Acta 1770: $1212-1218$

42. Kryatov SV, Mohanraj BS, Tarasov VV, Kryatova OP, RybakAkimova EV (2002) Nickel(II) complexes with tetra- and pentadentate aminopyridine ligands: synthesis, structure, electrochemistry, and reduction to nickel(I) species. Inorg Chem 41:923-930 